\title{
コルヒチントヘテロアウキシント， 生理學的細胞學的關係
}

\author{
征矢野芳孝 \\ Yoshitaka Soxano: Physiological and Cytological Relations between \\ Colchicine and Heteroauxine.
}

Received February 10, 1940.

コルヒチンガ種々ノ植物二倍數性习誘導スルト同時ニ著シイ異常肥大ヨ起サセル 事八周知ノ事實デアルガ，コノ異常肥大ノ形狀八容易二我々ヨシテ植物生長素 $=$ ヨ ル癌狀肥大現象ヨ想起七シメル。

LEVAN (1939) 八數種ノ生長素デたまねぎノ根端习處理シ, Naphthalene-acetic acid ト Indolyl-butyric acid トガ極メテ顯著ナ異常肥大ヨ起サセル事习觀察シ，コ レラノ異常根端フ細胞學的二檢討シタ結果, 分裂組織二八何等異常ナク，伸長區域 ノ皮層細胞中二倍數性ヨ發見スル事ガデキタ。ソシテコレラ倍數性細胞八正常ノモ ノョリモ著シク細胞容積ガ大デアルノヨ見夕。

氏ハコレニ對シ次ノ推論 マ下シテ居ル，細胞ノ容積ノ生長素ニョル堆大二對シテ 細胞內容ガ調和適應セントシテ，ソノ結果染色體數ノ静止核狀態二於ヶル倍加ガ生 ジタモノデアルト。上記ノ研究結果カラワカル樣ニコルヒチント生長素卜ノ倍數性 誘導作用八本質的二趣习異ニスル事入明カデアルガ，生長素ニヨル翼常肥大八必ズ

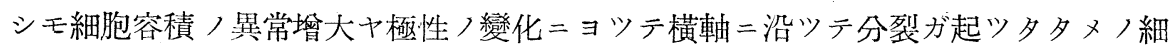
胞列ノ增加等ニソノ原因ョ歸セシメルベキデハナク，一次的二八極性ノ消笑ニヨル

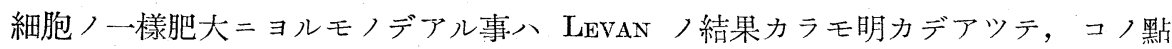
コルヒチン）第一次翼常肥大（征矢野 1939, 1940）トソ〉趣习同ジウスル。

サテコ、ニコルヒチン八果シテヘテロアウキシンナドノ樣二細胞，生長 ルモノデアルカト云フ疑問ガ起ルガ, HAVAS (1938) 友ビ MÜNTZINa (1939) 等=ョ ツテ，コルヒチンハ植物ホルモンデハナイガ生長素/活動力ノ增大スルモノデアル ト云フ結論ガ與へラレタ。而シ AVERY 等 (1939) ノ切頭法ヨ施シタからすむぎノ子 葉鞘試驗ニョルトコルヒチンニ八明カナ生長抑制作用ノアル事ガ示サレテキル。コ ノ實驗デハ切頭 ニョツテ生長素/形成移行ヨ消滅サ七テ立ルカラ, ソノ實驗結果ガ AVERY 等ノソレト異ツテモ必シモ矛盾シタ事デハナイ。

Mendes (1939) 八發芽種子ヨ高濃度デ處理シ夕際二生長抑制作用ア示ス根ノ發達 ガ Indole butyric acid 7 加ヘル事ニヨツテ促進サレル事ヨ見出シタ。

上記，諸交獻カラ考ベルニ，AVERY／生長素生理活動增强說八充分眞實性ヨ有ス

1) Contributions from the Divisions of Plant-Morphology and of Genetics, Botanical Institute, Faculty of Science, Tokyo Imperial University, No. 247. 


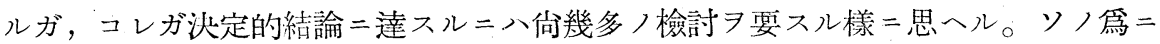
八先ヅコルヒチントヘテロアウキシンニ共通ナ上記異常肥大現象ノ本質习生理學的 二檢討スルコトガ極メテ重要デアル。コノ論文ハカ、ル見地カラ追求セラレタ實驗 結果ノ報告デアル。

\section{實驗觀察 1 コルヒチン處理ニヨリそらまめノ嫰枝ノ腋芽ニ 現レタ異常肥大}

良形中型ノそらまめヨデキルダケ古イ鋸䝠习詰メ夕數個ノ素燒ノ 5 寸鉢= 1 錸二 10 粒アテ播種シ，溫室中二嫰芽ガ大體 3-5 寸程度二伸ビルマデ放置シタ。

最初ノ真葉ガ第四節間二現レ始メ夕時二, 芽ヨコノ節ノ下, 凡り $1 \mathrm{~cm}$ ノ所デ切頭 シ, $0.2 \%$ ノコルヒチン溶液及ビ飽和ノヘテロアウチシン溶液フ試驗植物ノ切斷面二 ピペットデ滴下シタ。

處理植物八實驗開始後 5-10日二亘ツテ觀察シタ。ソノ結果八次ノ如クデアル。

ヘテロアウキシンデ處理シタ植物ニ對シテハ既= LAIBACH 及 FISCHNIT (1935) = ヨツテ報告サレタ樣ナ暴常肥大ガ觀察サレタ(第 1 圖)。マヅ處理後 3 日目二八明カ 二切斷面直下二癌狀肥大ガ起り, 次第ニソノ大キサヨ增大スル。ソシテ 1 週間後二 ハコノ肥大部カラ側枝發生ノ兆候ガ認メラレタ。而シコノ異常肥大部ノ下ノ葉腋二 發生シテ圭儿腋芽二八對照二比較シテ何等異常习認メル事八デキナカツタ。コレラ ノ異常肥大部 7 細胞學的二調ベテ見ルト，柔組織細胞ノ容積增大，側枝ノ發生，組 織ノ木質化等ガ見ラレタ。故二上記癌狀肥大ノ直接ノ原因八柔組織細胞ノ生長促進 卜夥シイ側枝ノ發生二歸セラレル。

コルヒチン溶液デ處理シタ植物ハ 1 週間後二至ツテモ蒸ノ切斷面二八何等異常ガ 現レズ全ク對照ノソレ二類似スルガ，奇異ナ事二切斷面カラ下ノ葉腋二發生シテ年 ル腋芽八異常二肥大シ，其後 2 週間ヨ過ギテモ殆ド伸長セズ舊態ヨ維持ズル（第 1
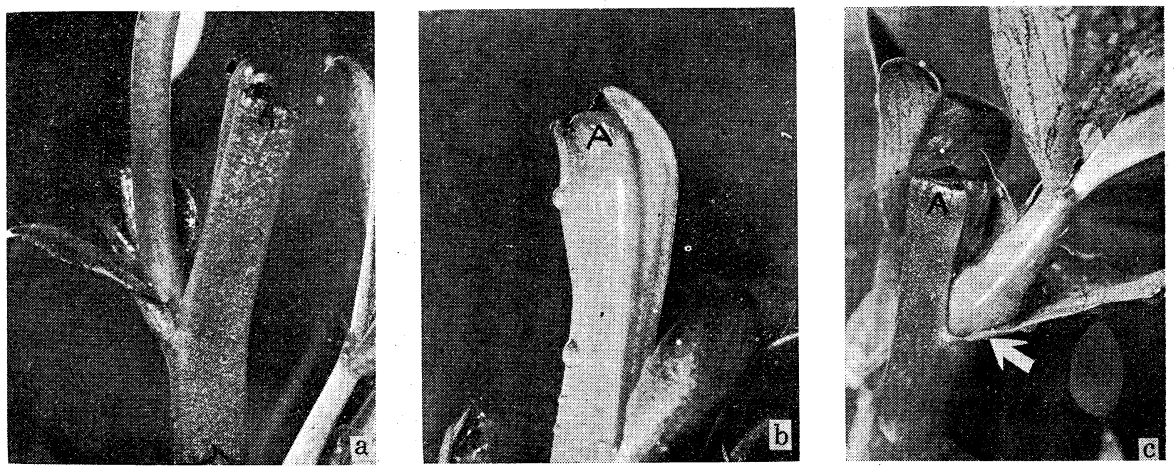

第 1 圖 そらまめノ莖习用イタコルヒチン及ビヘテロアウキシンノ比較實驗

a）對照。b) ヘテロアウキシンニヨッテ生ジタ異常肥大。 c) コルヒチンニヨッテ生ジタ切 頭下, 葉腋ノ腋芽, 異常肥大 (白)矢印)。 $\mathrm{A}$, 切頭 場所。 
圖 c)。コノ實驗入えんぎうヨ材料二使フトソノ敏感性ノタメ二更二著シク肥大シタ 殆ド球形二近イ異常芽ヨ得儿事ガデキル。

カクシテコルヒチンガ切斷面直下ノ伸長區域ノ細胞二八殆ド影響ヨ與へズニ何等 カノ經路习巡ツテ莖中 下降シ腋芽二到達シテコ、デ先ヅ初メ二伸長區域ノ細胞二 作用シテ異常肥大ヨ起サシメ次デ分裂組織ノ細胞二倍數性ヨ誘導シ巨大細胞 セシメタト考へル事ガデキル（征矢野 1939, 1940）。

上記ノ結果カラシテ，生長素作用トコルヒチン作用卜八異常肥犬゙习起ス樣子二於 テ著シイ差異ノアル事ガワカル。

最後二著者八ヘテロアウキシンノ飽和溶液トコルヒチンノ $0.2 \%$ 溶液トラ等量 混合シコレヨ腋芽ノ頂端二塗抹シタ所，コルヒチンヨ單獨二使用シタ場合ヨリモカ ナリ急速ナ，ソシテヌ著シイ異常肥大ヨ觀察シ得タ。ココデ一考 要スル事八嫰枝 ノ切頭直下二殘サレタ伸長區域二異常肥大ガ生ジナカツタ事實デアル。著者 (1939) 八震ニコルヒチンニヨル根ノ異常肥大八二大別スル事ガデキ，ソノ一ツハ伸長區域 ノ細胞ノ極性ノ沙夫ニョルト見ラレル異常肥大デアル事ヨ豫報シタ。故ニコレ等互 二矛盾スル如クミエル二結果八伸長區域卜分裂組織區域卜ガ共存隣接スルカ否カ 考慮スル事ニヨツテ說明スル事ガデキル樣二思ヘル。

そらまめノ實驗デハ嫰枝ノ切頭フ行ツテサルカラ，分裂組織八倨瞭二伸長區域上 部カラ除去サレタ譯デアル。シカルニ腋芽二於テハ分裂組織卜伸長區域八共存スル カラ：モシ切頭部/伸長區域異常肥大ヨ行ハズ下部/腋芽ガ異常肥大ヨ示シタトス レバ, コレハ明カ $=$ 分裂組織ノ存在ガ伸長部/異常归大惹起二關係アル事ヨ示唆ス ル。コ、二於テ異常肥大八分裂組織內ノ細胞分裂ソノモノ二關係スルカ，又八分裂 組織中二形成サレル何等カノ物質 (恐ラク植物生長ホルモン) テ殘サレル。コノ問題习解決スルタメ二次ノ如キからすむぎノ實驗习行りタ。

\section{實驗 2 コルヒチン處理ニヨルからすむぎノ子葉䩗ノ異常肥大}

暗室定溫槽中デ發芽七シメタからすむぎノ種子ヨ $0.05 \%$ ノコルヒチン溶液デ處理 シタ。子葉鞘ノ長サニョリコレヨ三リニ分ケ $(2-3 \mathrm{~mm}, 5 \mathrm{~mm}, 10-15 \mathrm{~mm})$ ペトリシ ヤーレ中二瀘紙ヨ敷キ,コノ上 $=5$ 粒ヅツ發芽種子ヨ載セ暗箱中二放置シタ。

子葉䩞ノ長サ 2-3 mm / 處理植物ハ 24 時閒後二小根端及ビ子葉鞘ノ顯著つ・異常 肥大ヨ示シタ (第 2 圖)。コノ根端異常肥大八圖カラ見ラレル樣二第一次異常肥大デ アル。子葉䩗ハコルヒチンノ作用ニヨリソノ伸長生長习完全ニ抑制サレ長サ八處理 前ノモノト殆ド變ラナイ。48時間後ニナルト根端ノ第一次異常肥大八昵膫二第二次 異常肥大二移行シテ尖棍棒狀トナリ，伸長生長入完全二抑制サレル。子葉鞘八多少 ノ伸長习見七大體處理前ノ種子ノ長サトナルガ, 異常肥大八活潑二進行スルタメソ ノ形狀ハアタカモ種子ノソレノ樣デアル。

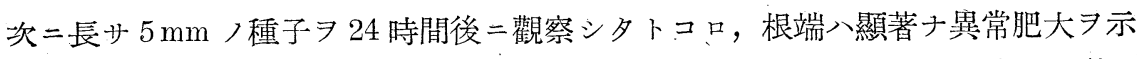
シ，子葉䩗八僅カ二伸長シタママ生長 7 停止シ, 唯處理前)子葉䩗二比較シテ約 2 


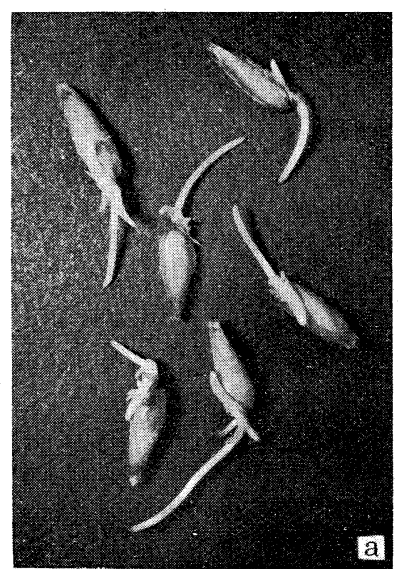

第 2 圖 長サ $2-3 \mathrm{~mm}$ a) 處理前, 種子。
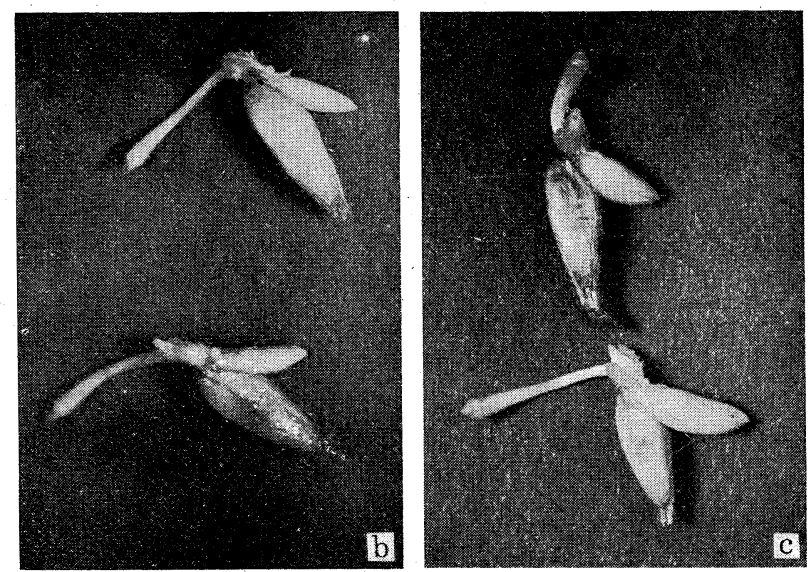

c.

八子葉鞄 ヨコルヒチンデ處理シタ際二生ジタル異常肥大
b) 24 時間後,モノ。
c) 48 時間後ノモノ。

倍ノ幅ヨ有スル事がワカツタ(第 3 圖)。48時間後二八根端ノ異常肥大八第二次異常 肥大ノ形狀习呈シタガ子葉䩪ノ樣子二八殆ド變化ガナカツ夕。

最後二長サ 10-15 mm，子葉鞘习有ス儿發芽種子，場合八 24 時間後二八根端異常 肥大八第一次異常肥大型ヨ示シ子葉鞘ハヤヤ伸長シタガ, 嶫监ノソレト比較スルト 著シイ長サノ差異ガミラレタ。幅モ僅カ二增大シテ年夕。コ/處理植物八5日間放 置シタトコロ, 子葉鞘ノ基部八裂開シテ異常肥大シ夕芽ガ現ハレタ。コノ際子葉䩗 ノ長サ八對照, $1 / 3$ 二過ギナカツタ。

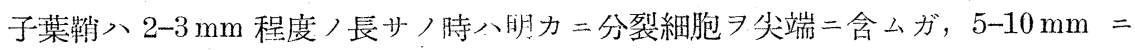
ナルトモハヤ子葉䩪ノ細胞八分裂习停止スル事习著者八觀察シタ。故 $=5-10 \mathrm{~mm}$ 程 度ノ子葉鞘ガモシコルヒチン處理ニョツテ多少トモ異常肥大ヨ示スナラバ，異常肥 大八細胞分裂りノモノト八關係ガナイ事ニナル。上記ノ實驗結果八著者ヨシテ異常 肥大八細胞分裂ソノモノニ八關係ガナイトイフ推論ヨナサシメタ。故二前項とらま めノ實驗結果习綜合シテ分裂組織區域ニ形成サレル何等カノ物質ガコイ異常肥大二 直接關係シタト考へル事ガデキル。コ，假定物質ガ恐ラク植物生長素デアルト云フ 考八光分理由ノアルコトデアルガ, コノ點ヨ吟味スルタメ二次二からすむき,子葉 䩪ノ屈曲實驗习行ツ夕。

\section{實驗觀察 3 ユルヒチン及ビヘテロアウキシンニヨツテ屈曲シタ からすむぎノ子葉䩗}

試驗二用七タからずむぎ, 子葉鞘力゙ 25-40 mm 二達シタ時, 次ノ如クシテ切頭 シタ。片側ノ切頭八尖端カラ 2-3 mm /トコロデ安全剃刀ノ斥デ行ヒ, 子葉鞘頭端 ７除去シタ。カクテ斷面カラ第一葉ガ出ル。コ葉八徐口二引拔キ子葉鞘ノ中二葉 ノ基底ガ $5 \mathrm{~mm}$ 程殘儿樣ニシタ。ソシテ突出セ儿葉ノ部分八葉鞘ノ尖端カラ上方 
$5 \mathrm{~mm}$ /所デ切ツタ。 カク裝備サレ夕子葉 鞘ニラノリン軟亳卜 ナシタコルヒチン及 ビヘテロアウキシン タ片面ニツケタ。コ ルヒチン及ビへテロ アウキシン八前者八 $0.2 \%$, 後者八飽和溶 液デアル。コノ試驗 二於テ，負八屈曲八 生長促進 7 意味シ, 正ノ属曲八生長韭滯 ヨ示ス。

飽和ノヘテロアウ キシンデ處理シタが らすむぎ/子葉郘八 4 時間後二八明カー 負ノ屈曲 7 示シ 24 時 .間後二八一趈轉シタ (第 4 圖a)。

コルヒチンデ處理 シタ子葉鞘八 3 時間 後二於テモ何等屈曲
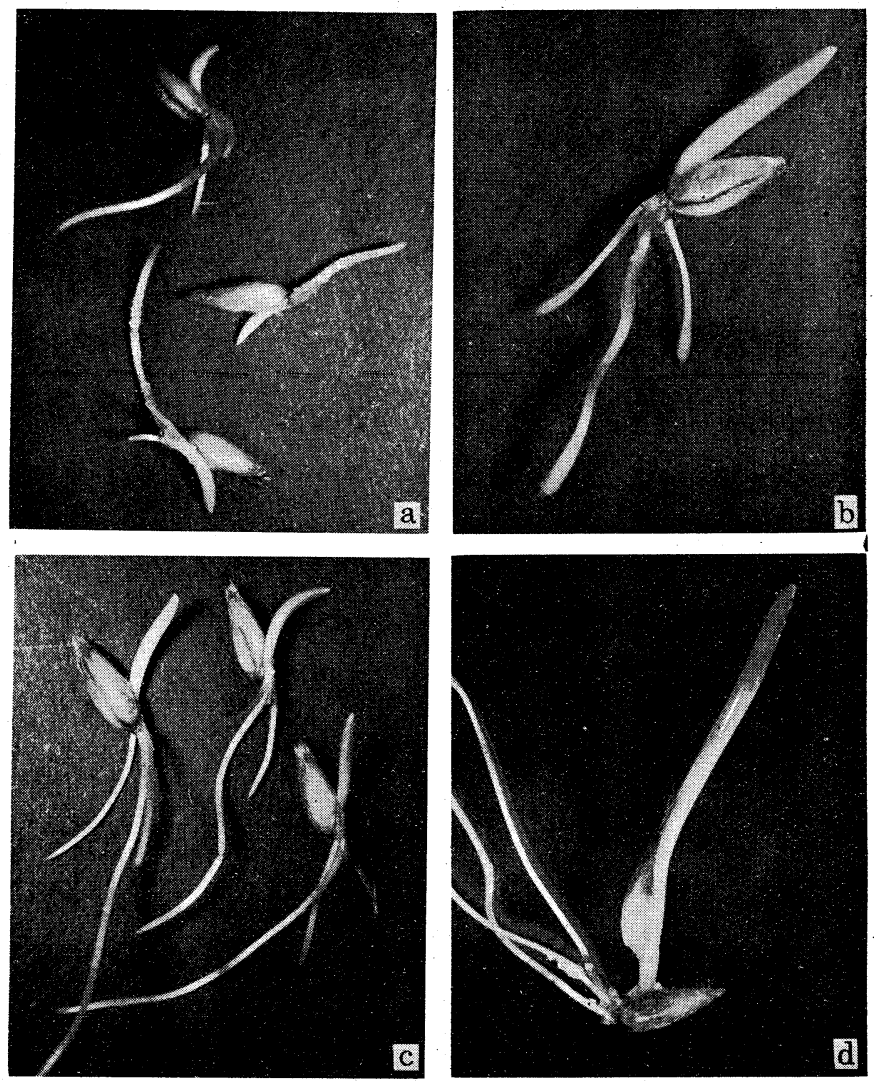

第 3 圖 a) 長少 $5 \mathrm{~mm}$ /子葉鞘 7 有 スル種子。 b) コルヒチン處 理， 24 時間後二（a），種子二生ジタ異常肥大。 c). 長节 $1 C-15$ mm ，子葉鞘习有スル種子。d）(c)，種子ヨ5 日間コルヒチンデ處理シ タ際二生ジタ基部, 異常肥大。

ヨ示ス事ナク，唯二

三ノモノガ 24 時間後二微カナ正ノ屈曲ヨ示ス二過ギナカツタ（第 4 圖 b, c)。侗子葉 鞘八處理後 1 週間後二至ルモ異常肥大八ナカツタガ，基底:ヤ、膨大ガミラレタ。

コレハ子葉䩗ソノモノノ膨大デハチイ樣二思ハレル。

次二切頭ヨ行フ事ナシ二子葉鞘ノ屈曲試驗 ヨ行ツタ。ソノ際使用シタコルヒチン ノ濃度八次ノ如クデアル。
$0.0002 \%$
$0.002 \%$
$0.02 \%$
$0.8 \%$

隌室中デ凡ソ $1 \mathrm{~cm}$ 二伸ビタ子葉鞘习上記ノ濃度ノコルヒチンデ處理シタ所, 2 日後 二於テ $0.0002 \%$ ノモノ八全ク正常卜變ラズ, $0.002 \%$ ノモノモ殆ド變化ナク，0.02\% ノモノ八正ノ属曲及ビ異常肥大ヨ示シ，0.8\%ノモノ八異常肥大微弱デ，僅カ =正ノ 屈曲习示シタ (第 5 圖)。

コノ場合最モ興味アルノハ $0.02 \%$ ノコルヒチンガ異常肥大卜正ノ属曲卜ヨ行フ事 デアル。コレヨ細胞學的二觀察スルト，處理面ノ側ノ細胞八極性ヨ失ナツテ一樣肥 

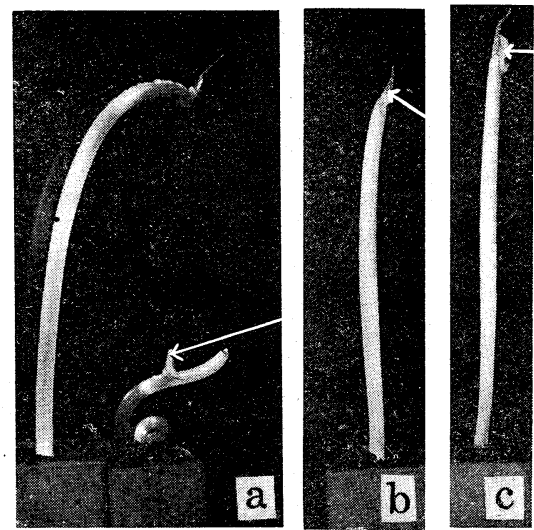

第 4 圖 切頭ヨ行ツタからすをぎ子葉鞄 八屈曲賽驗。

a. ヘテロアウキシンニョル子葉䩵〉属曲。 b, c. コルヒチン處理习受ケタ子葉䩪。
大生長ヨ行ツテ居リ，ソレト反對側ノ細胞 八正常ノ縱長ノ生長习行ツテキル。モシ單 ニコルヒチンガ細胞つ極性二八無關係二唯 ソノ長長习抑制シタトスレバ，カ、ル異常 肥大ヨ伴フ事ナシ二唯正ノ屈曲ダケヨ示シ タデアラウ。故二上記ノ結果カラ考へルト コルヒチンノ正ノ属曲八全體トシテノ生長 抑制デハナクテ唯單ニソノ極性习渻失又八 變化セシメタコト二原因スル。佾コルヒチ ン處理习受ケ夕子葉鞘八處理溶液)濃度ガ 極メテ低イ場合二於テモ對照ヨリモ生長ガ 後レタト云フ事實八, 該物質ガ生長促進作 用ヨ生長素ノ有無二係ラズ示サナイト云フ 推論 ヨナサシメル。

切頭 屈曲及ビ異常肥大ヨ示サ ズ，切頭ヨ行ハヌ子葉鞘 ガ特異ナ属曲习示シタ下 云フ事實八，そらまめ， 實驗結果卜對照比較スル 卜キ二，生長素ノ形成移 行ガ, 異常肥大惹起二關 係スル事ヨ示唆スル。

著者八ひまわりノ甲析 實驗ニョツテ，更二檢討 ヨ行ツ夕。

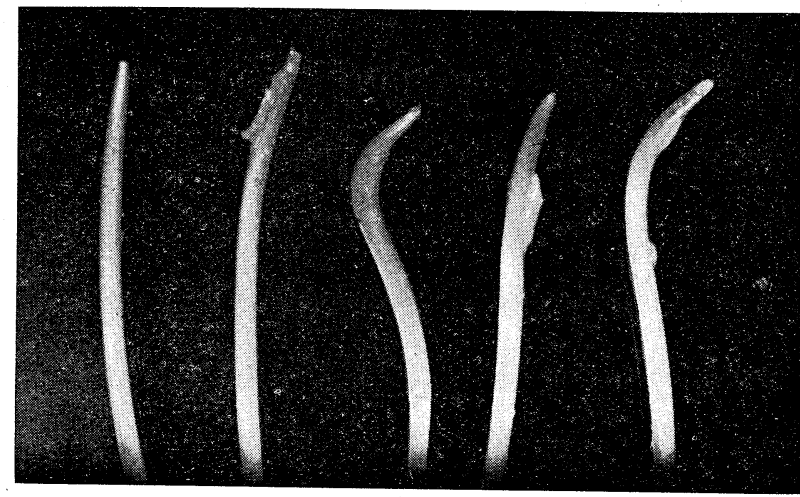

第 5 圖 コルヒチン處理ニヨルからすむぎノ子葉鞘／屈曲賽驗 左 ヨリ $0.0002 \%, 0.002 \%, 0.02 \%, 0.8 \%, 0.8 \%$ /ニルヒチン溶 液デ處理シタ子葉鞘。

\section{實驗觀察 4 コルヒチン及ビへテロアウキシンニヨツテ生ジタ びますりノ甲析ノ異常肥大}

喑室デ石英砂フ詰メタ小素燒鉢! 中ニひまわりノ種子フ播キ, 幼莖ガ凡り $2 \mathrm{~cm}=$ ナツタトキ,コレララ飽和ノヘテロアウキシント $0.8 \%$ ノコルヒチンデ處理シタ。子 葉下ノトコロ二環狀ニヘテロアウキシントコルヒチンノラノリン軟高习塗リツヶ 5 日後二取出シテ觀察シタ。

ヘテロアウキシンデハ處理部二顯著子異常肥大ガ起ルガ幼芽八肥大部ノ上部デ生 長シテ阻害作用タウケナイ。トコロガコルヒチン處理, 甲析八子葉下, 處理部二顯

1）著者ハ $0.0002 \%$ 以下/溶液入使用シナカタカラ更二低濃度デ子葉䩗〉生長が促進サレタ トスレバ,コノ推論八訂正サレネバナラヌ。 
著子異常肥大ヨ生ズルト同時二處理上部ノ莖ノ伸長ヨモ抑制スル。コレハコルヒチ ンガ處理部伸長區域, 細胞, 極性 フ消失セシメルト同時二分裂組織ノ細胞二働イテ 異常核分裂习誘導シ，著シイ倍數性ニヨツテ植物體入生長阻害ヨ受ケタタメデアル ト考ヘラレル。

\section{論考}

以上著者八極メテ概括的ニデハアルガ，コルヒチントヘテロアウキシンノ作用， 間ノ關係 二就デ諸種”比較實驗結果习述ベタガ，コレラヨ次ニ綜括的二論考シテ HAVAS (1938)）說ヨ檢討シテミョウト思フ。

切頭 行ハヌ子葉鞘ノコルヒチン二對スル反應結果カラ示サレル樣二，コルヒチ ン八生長促進劑デハ勿論ナク，直接的二八植物生長抑制劑デモナイ。何故トナラバ 生長抑制劑卜ハ自身生長抑制 行フ物質デハナクテ生長素ノ活動力ヨ抑制スル物質 デアラネバナラヌ。コレハ生長素ガ生長ノ決定的ナ要因デアツテ單ナル外的促進劑 モシクハ增强劑デハナイト云フ所說カラ考へレバ明カナ事デアル。

コルヒチンハ上記諸結果カラ見ラレル如ク細胞ノ極性フ變化セシメルニ止マリ， 肥大生長二入何等關與シナイモノノ樣デデル。コレハコルヒチンガ生長素ノ活動二 對シ干涉シナカツ夕事习示シテ年ル。故ニコルヒチン處理ニヨツテ生ジタ伸長區域 ノ異常肥大ハコルヒチンノ極性消失作用卜生長素ノ肥大生長作用ノ二重作用 $=ヨ ル$ モノト推察サレル。モシ細胞ノ極性ガ存在スルトキハ細胞八生長素ノ働ニョツテ所 謂正常ノ生長ヨナスデアラウガ，コノ生長素モ濃度强大ノトキ八該物質ノ本質的子 作用ノ外二極性消尖ノ作用ガ現ハレ，丁度コルヒチントノ協力作用ニヨルノト同ジ 結果习導イテ，ココニひまわりノ實驗ニ於ヶル樣ナ類似ノ異常肥大ガ生ズルモノト 思ハレル。而シ生長素八分裂組織二八何等影響习與ヘナイタメ゚ニコルヒチンノ樣ナ 著シイ後作用 伴フ事ナク，作用部二滲太シタ生長物質ガ他部二分散移行スル事二 ヨツテ稀薄ニナツタ後ニハ正常う，モシクハムシロ促進的ナ生長ガ伸長區域二現八 レルモノト思ハレル。

著者ハカナリ稀薄ナコルヒチン處理ニヨツテモ切頭ヨ受ケヌ子葉䩗ガ促進的生長

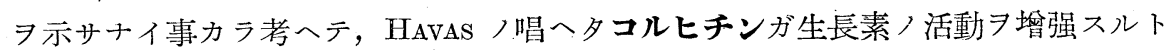
云フガ如キ說八首肯デキナイ。

占 MÜNTZING（1939） ガ報告シタ稀薄ナコルヒチン溶液デ處理サレタ種子ノ生長 ノ增大八、ソノ濃度コルヒチン八植物ノ生長二八何等直接二八作用シナイガ種子， 殺菌ヨカナリ迄有效二行ツ夕事ニヨルモノデハナイカト思ハレル。

少コルヒチン八稀薄ナ酸二對シテモカナリ弱イ物質デアルタメ，コルヒチン處理 ノ植物ヨ生長物質デ再ビ處理ズル事ニヨリコルヒチンノ分裂阻害作用八生長素ノ酸 ノ性質ニョリ急速ニ消滅サレルデアラウ。MENDES (1919) ) 實驗結果八恐ラクカ、 ル兩物質ノ化學的反應 $=ヨ$ ヨテ說明サレルト思ハレル。 
此報告ヨ終ル二當り論文作製ノタメ二御指導ヨ賜ツタ復遠助敉授及ビ種々ノ御助 カヨ下サツタ敎室ノ諸兄二對シ深ク感謝ノ意ヨ表ス。

\section{東京帝國大學理學部植物學教室}

\section{文獻}

Avery, G. S. and SARgENT, G. B. 1939. The effect of various compounds upon straight growth of the Avena coleoptile. Amer. Jour. Bot. 26: 548-554.

Havas, L. J. 1938. Is colchicine a "phytohormone?" Growth 2: 257-260.

Levan, A. 1939. Cytological phenomena connected with the root swelling caused by growth substances. Hereditas 25: 87-96.

Mendes, A. J. T. 1930. Duplicaçao do numero de cromosômios em café alogodaô e famo, pela ação da colchicina. Bol. Tée. See. Agrie., Indústr: Com. S. Paulo. $57: 1-21$.

MÜnTZing, A. and Runquist, E. 1939. Note on some colchicine-induced polyploids. Hereditas 25: 491-495.

征矢野芳孝 1939. “三化學物質/細胞核二及ボス影響（豫報）。植雜 53: 275-279.

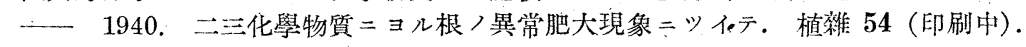

\section{ほんだはらノ生殖窗ノ發生}

田原正人

Masato TaHara: The Development of the Conceptacle of Sargassum.

Received March 25, 1940.

生殖窠 (Conceptacle) ハフークス科 (Fucaceae) ノ最モ重要子特徵ノ一ツデ，コ レニ閵シテハ，既二古クカラ色々ノ研究ガ行ハレテ居ルガ，1906 年二公ニサレタ SIMONS /研究八劃期的ノモノデ, 生殖巢ノ發生二關シ現在吾々ノ持ツテ居ル知識, 基礎入，先ヅコノ研究ニョツテ築カレタトイツテ差支ガナイ。SIMONS 八大西洋沿 岸二產スル Sargassum filipendula トイフほんたはらノ一種ニヨツテ研究习行ツタ ノデアルガ，ソレマデ不明デアツタトコロノ，生殖巢ノ原始細胞 (initial cell) ガ生 殖巢ノ發生二際シ，極メテ重要ナル意義ヨ持ツモノデアルコトヨ, コノ研究ニョツ テ始メテ完全二證明シタ。ソノ後 1913 年二 NIENBURG ハヨーロッパ産ノ種々ナフ

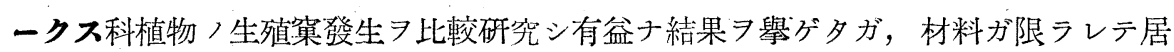
ルノデ，吾々日本人ナドカラ見ルト少シ物足リナイトコロガアル。例へバ我ガ國ナ ド二八極メテ普通デアルトコロ/はんだはら屬植物ノ如キヨ, NIENBURG 八全ク研 究シテ居ラメ。ソコデ筆者入本邦二普通ナ材料デ少シク詳細ニコノ方面ノコトラ研 究シテ見ヨウト企テタ。今日マデニ得タ結果ノ大要习下二述ベル。

先ヅ第一二症んだはら屬ノ代表卜シテ各地二極メテ普通デナルトコロノ、痤んだは 